\title{
Effect of immersion on urinary lead excretion
}

\author{
AUDREY HEYWOOD, ${ }^{1}$ H A WALDRON, ${ }^{2}$ P O'HARE, ${ }^{1}$ P A DIEPPE \\ From the Department of Medicine, ${ }^{1}$ University of Bristol, Bristol, and London School of Hygiene and \\ Tropical Medicine, ${ }^{2}$ London, UK
}

The physiological effects of water immersion in man were studied by Epstein ${ }^{1}$ in the 1970s in conjunction with the United States National Aeronautics and Space Administration's research into weightlessness. This showed that immersion up to the neck in water at $35^{\circ} \mathrm{C}$ produced a profound diuresis, naturesis, and an increased urinary excretion of calcium. These pronounced alterations in renal function brought about by immersion probably occur because the hydrostatic pressure of the water produces a redistribution of extracellular fluid in the body. There is a shift of about $700 \mathrm{ml}$ of blood from the limbs to the thoracicocardiac compartment. This increase in the effective extracellular fluid volume is thought to mediate the renal changes by hormonal mechanisms. A recently discovered hormone, atrial naturetic peptide, ${ }^{2}$ has been found to have a role in regulating these changes but is unlikely to be the only factor concerned.

One study of the treatment of lead poisoning by Bath Spa therapy during the eighteenth century ${ }^{3}$ has shown that a cure rate of about $49 \%$ was achieved in patients who had paralysis due to lead poisoning whereas in hemiplegias or paralyses of unknown aetiology the cure rate was only about $11 \%$ and about $6 \%$ when the condition was secondary to spinal deformity.

Admission to the Bath Hospital was conditional on the charity patients complying with the prescribed treatments and they were not discharged until a committee of the attending physicians considered that they had obtained the maximum benefit from the spa treatment and had agreed on both diagnosis and outcome. The doctors were to keep good records, an analysis of which was published annually. It was stated that many of the patients had been discharged as incurable from other hospitals before their admission to Bath. Between 1751 and 1758, 15 of the 31 patients with occupational exposure to lead had been referred from London hospitals as incurable; when they were discharged after a stay at the Bath Hospital, seven were cured and eight were much improved.

Spa therapy was multifactorial necessitating removal from exposure, a change in diet (probably for

Accepted 24 March 1986 the better), increased exercise, and a regimen that required the patient to drink the mineral water daily and to be immersed in the bath three times a week. Knowing that immersion affects the urinary excretion of calcium and that the metabolism of lead and calcium are closely related, we decided to investigate the effects of immersion on the rate of urinary lead excretion to see if this might have contributed to the successful treatment at Bath.

\section{Methods}

Three lead workers with moderately raised blood lead concentrations volunteered to be immersed and were compared with seven control subjects. ${ }^{4}$ A 24 hour urine specimen was collected the day before immersion. No food or water was taken after 2230 on the day before the experiment. At 0730 on the day of the immersion a water load of $400 \mathrm{ml}$ was taken but no food. At 0830 the subjects emptied their bladders and drank a further $200 \mathrm{ml}$ of water. The next hour was spent sitting outside the tank on chairs identical with those in the tank. After one hour sitting outside the tank the subjects emptied their bladders, drank $200 \mathrm{ml}$ of water, and entered the tank. As this had been converted from a jaccuzi it was possible to maintain the temperature of the water at $35^{\circ} \mathrm{C}$ throughout the immersion period and to adjust the water to be level with the suprasternal notch when they were seated in the tank. They remained in the tank for three hours, getting out at hourly intervals to empty their bladders and to drink $200 \mathrm{ml}$ of water before continuing the immersion. At the end of the third hour they spent a further hour sitting outside the tank. The subjects were weighed before and after immersion and blood samples were taken on both occasions. The urine volume was measured hourly. Urinary lead concentrations were measured by atomic absorption spectrophotometry.

\section{Results}

The subjects excreted a mean excess of water of $552 \mathrm{ml}$ which was accompanied by a mean loss of weight during the immersion period of $0.53 \mathrm{~kg}$. The mean 


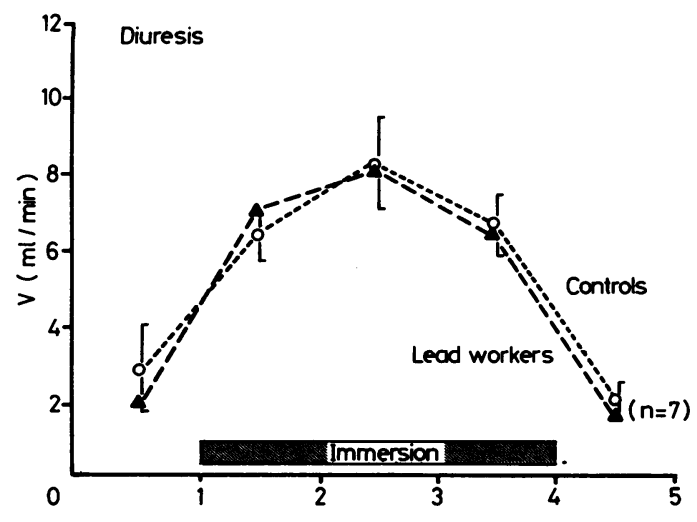

Fig 1 Diuretic effect of immersion therapy in normal and lead exposed subjects.

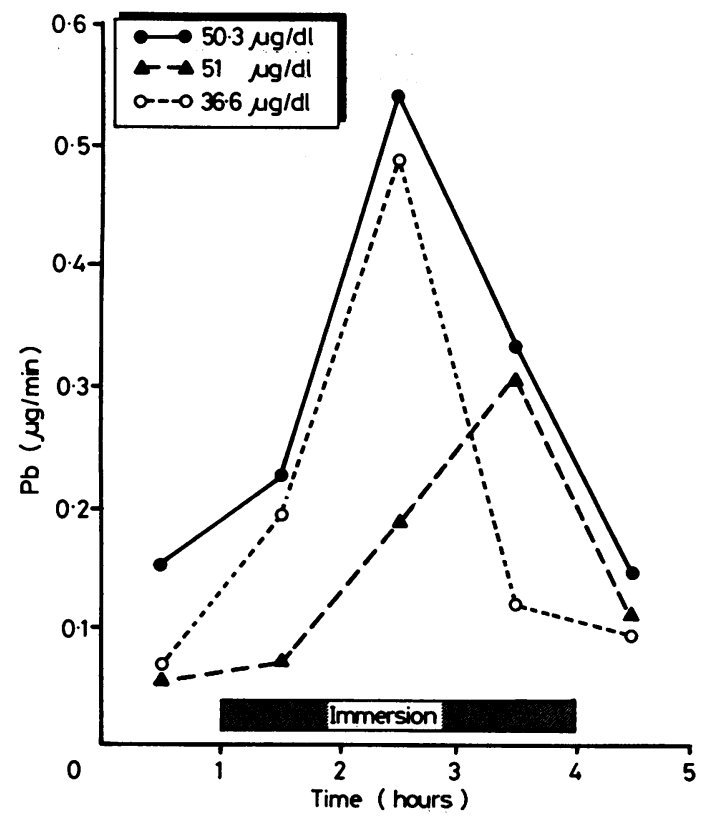

Fig 2 Effect of immersion therapy on urinary lead excretion.
Heywood, Waldron, O'Hare, Dieppe

urinary volume increased from $2.11 \mathrm{ml} / \mathrm{min}$ during the pre-immersion period to $8.16 \mathrm{ml} / \mathrm{min}$ in the second hour. This profound diuresis was similar to that of the seven normal subjects immersed under identical conditions (fig 1). The pronounced diuresis and naturesis produced by the immersion of these subjects was similar to that reported in our previous study. ${ }^{5}$ No significant change occurred in creatinine clearance on immersion. There was a considerable increase in the rate of urinary lead excretion from $0.09 \mu \mathrm{g} / \mathrm{min}$ preimmersion to $0.40 \mu \mathrm{g} / \mathrm{min}$ in the second hour (fig 2). The total amounts of lead excreted hourly by each subject are shown in the table. The urinary lead concentrations of the normal subjects were too low to be measured.

\section{Comment}

The results of our study suggest that immersion might have contributed in some part to the successful treatment of lead palsy at the Bath Hospital for although the increase in the amount of lead excreted in the urine during three hours immersion is small, bathing for up to an hour was repeated three times a week as part of the hospital regimen. So the increase in the total amount of lead excreted brought about by bathing may have been large enough to change appreciably the patients' prognosis. This has yet to be studied.

The historical evidence shows that spa therapy wase more effective in the treatment of paralysis due to lead poisoning than the conventional treatments with purges and opiates which were generally used during the eighteenth and nineteenth centuries. Factors other than immersion must also have contributed to the successful outcome. One was that admission to the hospital effectively removed the patient from his exposure to lead whether caused by his occupation or lead adulterated alcohol. The town water supply was hard and therefore free of lead. In addition, following the regimen at Bath meant that the patient drank between one and one and a half pints of mineral water a day. This water contains $393 \mathrm{mg} / \mathrm{l}$ of calcium and $1.45 \mathrm{mg} / \mathrm{l}$ of iron. Both would tend to minimise the uptake of lead from the gut and to reduce toxicity of the lead that had already been absorbed.

During the mid-eighteenth century the hospital patients bathed three times a week, for up to an hour at a time, in the hot bath. Later, Falconer reported

Total amount of lead ( $\mu \mathrm{g})$ excreted in the urine each hour during immersion

\begin{tabular}{llllll}
\hline Subject & Pre-immersion & lst hour & 2nd hour & 3rd hour & Total \\
\hline 1 & $9 \cdot 60$ & 13.62 & 32.56 & 19.50 & 65.68 \\
2 & 4.35 & 11.55 & 28.80 & 7.04 & $47 \cdot 39$ \\
3 & 3.60 & 4.20 & 11.40 & 18.50 & $34 \cdot 10$ \\
\hline
\end{tabular}


that cures were quicker when the cooler cross bath was used. ${ }^{3}$ When in 1830 the hospital had its own bath installed it was kept at $94-96^{\circ} \mathrm{F}\left(34-35^{\circ} \mathrm{C}\right)$. Immersion at this temperature has been shown by modern studies to produce the optimal effect on renal function. ${ }^{4}$

The effect of drinking the waters is yet to be studied.

We thank the Bath City Council and the Swain Foundation who funded AH during the period that this study was carried out. We would also like to thank $\mathrm{Mr}$ Stephen Thomas, Mr Jos Campbell, and Dr WGB Benson of Sheldon Bush Ltd for allowing us to study their volunteer employees.

\section{References}

1 Epstein M. Renal effects of head-out water immersion in man: implications for an understanding of volume homeostasis. Physiol Rev 1978;58:529-81.

2 Anderson JV, Millar N, O'Hare JP, McKensie RJC, Corrall RJM. Do circulating levels of atrial naturetic peptide (ANP) mediate the naturetic response to water immersion in man? Clin Sci 1985;69:39P.

3 Falconer W. On the Bath waters. 3rd ed. London: W Meyler, 1807.

4 O'Hare P, Heywood A, Summerhayes C, et al. Observations on the effects of immersion in Bath Spa water. Br Med J 1985;291:1747-80.

5 Heywood A, O'Hare P, Waldron HA, Dieppe PA. Gout, lead and spa therapy. Proceedings of the XVIth International Congress on Rheumatology, Sydney, 1985. Sydney: International League against Rheumatism, 1986:174.

\section{Vancouver style}

All manuscripts submitted to the $\mathrm{Br} J$ Ind $\mathrm{Med}$ should conform to the uniform requirements for manuscripts submitted to biomedical journals (known as the Vancouver style).

The $\mathrm{Br} J$ Ind Med, together with many other international biomedical journals, has agreed to accept articles prepared in accordance with the Vancouver style. The style (described in full in $\mathrm{Br}$ Med J, 24 February 1979, p 532) is intended to standardise requirements for authors.

References should be numbered consecutively in the order in which they are first mentioned in the text by Arabic numerals above the line on each occasion the reference is cited (Manson ${ }^{1}$ confirmed other reports ${ }^{2-5} \ldots$... In future references to papers submitted to the $\mathrm{Br} J$ Ind Med should include: the names of all authors if there are six or less or, if there are more, the first three followed by et al; the title of journal articles or book chapters; the titles of journals abbreviated according to the style of Index Medicus; and the first and final page numbers of the article or chapter.

Examples of common forms of references are:

1 International Steering Committee of Medical Editors. Uniform requirements for manuscripts submitted to biomedical journals. Br Med J 1979;1:532-5.

- Soter NA, Wasserman SI, Austen KF. Cold urticaria: release into the circulation of histamine and eosinophil chemotactic factor of anaphylaxis during cold challenge. $N$ Engl J Med 1976;294:687-90.

${ }^{3}$ Weinstein L, Swartz MN. Pathogenic properties of invading micro-organisms. In: Sodeman WA Jr, Sodeman WA, eds. Pathologic physiology: mechanisms of disease. Philadelphia: W B Saunders, 1974:457-72. 